\title{
Anti-CD3 monoclonal antibody as a possible therapeutic alternative in HAM/TSP
}

\author{
Johan Van Weyenbergh ${ }^{1,2^{*}}$, Daniele Decanine ${ }^{2}$, Saul Velloso Schnitman², Ana Maria Moro², Jorge Kalil2 \\ Ramon A Kruschewsky ${ }^{3}$, Bernardo Galvão-Castro ${ }^{1,3}$ \\ From 16th International Conference on Human Retroviruses: HTLV and Related Viruses \\ Montreal, Canada. 26-30 June 2013
}

Anti-CD3 antibody therapy is used to treat transplant rejection and has been applied in several autoimmune diseases, such as type I diabetes and ulcerative colitis, but its potential in HAM/TSP has not been investigated. Therefore, we explored the effect of ex vivo treatment (24-96h) of PBMCs from HAM/TSP patients $(n=15)$ and healthy controls $(n=20$, all from Salvador-Bahia, Brazil) with an anti-CD3 monoclonal antibody approved for in vivo treatment post-transplantation (produced under GMP conditions). In contrast to normal donors and patients in early disease stages, anti-CD3 treatment did not increase lymphoproliferation in PBMCs from advanced HAM/TSP patients (EDSS $>4$ ), but strongly induced apoptosis. In addition, anti-CD3 treatment did not induce a pro-inflammatory cytokine storm, either at the protein or mRNA level. Therefore, anti-CD3 treatment ex vivo might eliminate pathogenic $T$ cells through activation-induced cell death. Since we have previously shown that pro-apoptotic capacity decreases over time in HAM/TSP patients, both defective (Fasmediated) apoptosis and excessive lymphoproliferation, more pronounced in patients with advanced disease progression, can be restored by anti-CD3 treatment. Using microarray analysis, we found that treatment of HAM/ TSP PBMCs with anti-CD3 mAb had a pronounced effect on gene expression, significantly $(\mathrm{p}<0.001)$ downregulating 1918 genes (including pro-inflammatory genes) and up-regulating 1926 genes, including cell cycle-related and immunoregulatory genes, such as CTLA4. In conclusion, our results suggest anti-CD3 monoclonal antibody might be a possible therapeutic alternative in HAM/TSP, due to its immunomodulatory

\footnotetext{
* Correspondence: johan@bahia.fiocruz.br

'LIMI, LASP, Gonçalo Moniz Research Center (CPqGM), Oswaldo Cruz

Foundation (FIOCRUZ), Salvador-Bahia, Brazil

Full list of author information is available at the end of the article
}

effect, by inducing apoptosis, reducing exacerbated lymphoproliferation and stimulating anti-inflammatory gene expression and/or proliferation of cells with immunoregulatory capacity.

\section{Authors' details}

'LIMI, LASP, Gonçalo Moniz Research Center (CPqGM), Oswaldo Cruz Foundation (FIOCRUZ), Salvador-Bahia, Brazil. ${ }^{2}$ Institute for Immunological Investigation (iii-INCT), São Paulo, Brazil. ${ }^{3}$ Bahiana School of Medicine and Public Health, Salvador-Bahia, Brazil.

Published: 7 January 2014

\section{doi:10.1186/1742-4690-11-S1-040}

Cite this article as: Van Weyenbergh et al: Anti-CD3 monoclonal

antibody as a possible therapeutic alternative in HAM/TSP. Retrovirology 2014 11(Suppl 1):040.

Submit your next manuscript to BioMed Central and take full advantage of:

- Convenient online submission

- Thorough peer review

- No space constraints or color figure charges

- Immediate publication on acceptance

- Inclusion in PubMed, CAS, Scopus and Google Scholar

- Research which is freely available for redistribution

Submit your manuscript at www.biomedcentral.com/submit
() Biomed Central 